\title{
Aspek Lingual Tegursapa Sosial Masyarakat Jawa Kota Semarang
}

\author{
M. Suryadi \\ Fakultas Ilmu Budaya, Universitas Diponegoro \\ mssuryadi07@gmail.com
}

\begin{abstract}
The purpose of this study is to describe lingual aspects that strengthen the speech of the clergy of Java Coastal community in Semarang City. This greeting remarks as a glue of the socioal harmony and horizontal conflict absorbers, as well as a feature of uniqueness in the connection of social intimacy in the coastal region. Research location in Semarang City. Selection of respondents and informants using purposive sampling system. Data collection methods were conducted through structured interviews, in-depth interviews, and focus group discs. The method of data analysis using the separation of components on speech by greeting sad lingual aspects contained in the speech.There are three lingual aspects that influence the power of speech: speech sauce, variety, and form.
\end{abstract}

Keywords:greeting, lingual aspect, Javanese coastal language.

\section{Intisari}

Tujuan penelitian ini adalah mendeskripsikan aspek lingual yang memperkuat tuturan tegur-sapa social masyarakat Jawa Pesisir di Kota Semarang. Tuturan bertegur-sapa ini sebagai perekat harmoni sosioal dan peredam konflik horizontal, sekaligus sebagai fitur keunikan dalam pertalian keakraban sosial di wilayah pesisiran. Lokasi penelitian di Kota Semarang. Pemilihan responden dan informan menggunakan sistem purposive sampling. Metode pengumpulan data dilakukan melalui wawancara terstruktur, wawancara mendalam, dan focus group discus. Metode analisis data menggunakan pemilahan komponen pada tuturan bertegur-sapa melalui aspek-aspek lingual yang terdapat pada tuturan. Ditemukan tiga aspek lingual yang mempengaruhi kekuatan tuturan bertegur sapa social, yakni kecap ujaran,ragam, dan bentuk.

Kata kunci: bertegur-sapa, aspek lingual, bahasa Jawa pesisir.

\section{Pendahuluan}

Tuturan merupakan salah satu komponen terpenting dalam relasi sosial antarmanusia dalam kehidupan sehari-hari. Peran tuturan inilah akan memperkuat pertalian keakraban sosial di dalam masyarakat berbudaya. Kapan seseorang harus bertegur sapa dan kapan seseorang harus diam, semua diatur dalam pranata sosial dan strategi bertutur dalam kehidupan bermasyarakat, tercermin pada bagan-1. 


\section{Bagan 1: Strategi Bertutur dalam Pranata Sosial}

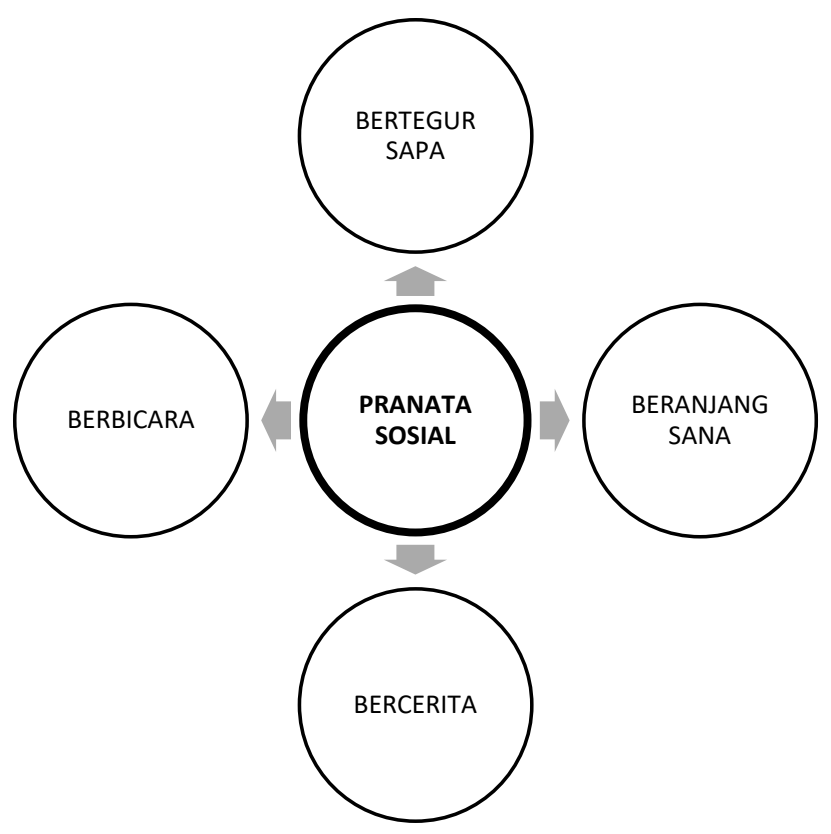

Pada bagan-1, pranata sosial mempengaruhi semua komponen tutur dalam peristiwa tutur, termasuk di dalamnya bertegur sapa, beranjang-sana, bercerita, dan berbicara. Bentuk korelasi pengaruh ditandai dengan $\Rightarrow$ (anak panah)

Ungkapan Jawa yang kerapkali muncul adalah wong Jawa kuwi kudu ngerti asale lan kapan kudu ngerti aturane.Ungkapan ini mengandung arti bahwa seyogjanya sebagai orang Jawa harus mengetahui asal-usulnya atau trah kelahirannya dan mengetahui pula adab budaya Jawa. Orang Jawa dalam kehidupan sehari-hari sangat menjunjung tinggi budaya untuk menjaga keselarasan dan harmoni sosial, yang semata-mata untuk mencapai keluhuran dalam menjaga keselarasan dengan alam.

Keselarasan dan harmoni sosial dapat terjaga melalui sarana bertegur-sapa. Bertegur-sapa salah satu wujud bentuk keramahtamahan, kepedulian sosial, silaturahmi dan menghargai terhadap sesamanya. Tegur-sapa dalam masyarakat Jawa memiliki dua bentuk, yakni bentuk verbal dan nonverbal (kegiatan fisik). Bentuk verbal dapat diwujudkan melalui ucapan/lisan. Bentuk kegiatan fisik diwujudkan melalui kunjungan/silatuhrami, kegotong-royongan, dan saling membantu, tercermin pada bagan- 2 . Pada tulisan ini tegur-sapa difokuskan pada kegiatan verbal, yakni sapaan sosial. 


\section{Bagan 2: Bentuk Tegur Sapa}

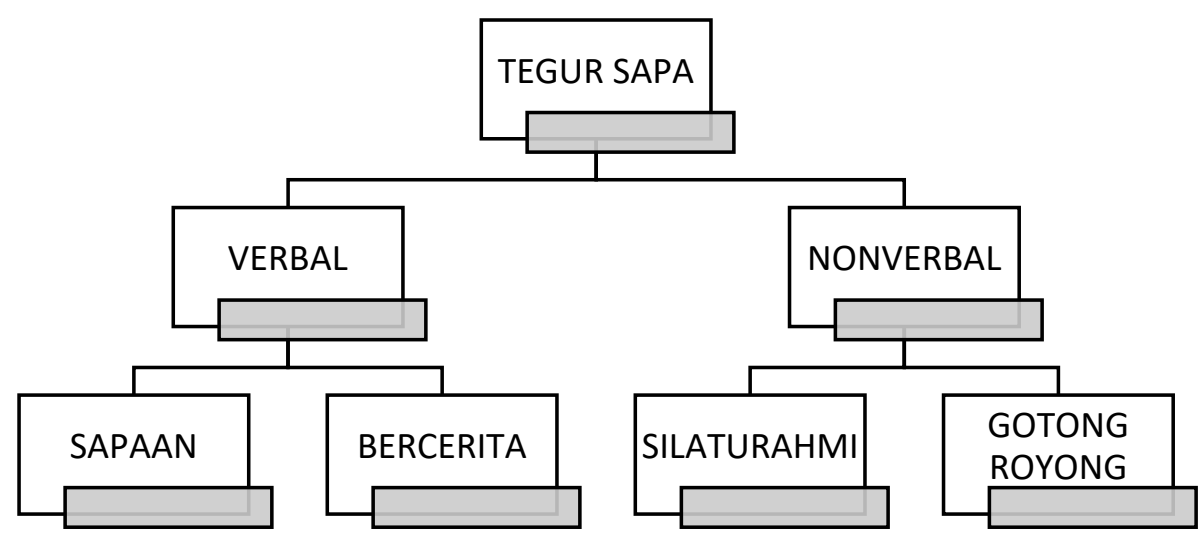

Kegiatan tegur-sapa tidak dapat dilepaskan dengan komponen lingual dan ektralingual. Komponen lingual terkait dengan bahasa yang digunakan, baik menyangkut bentuk, ragam, maupun tujuan. Pada posisi ini, penutur/penyapa memiliki kemampuan untuk memilih bentuk dan ragam bahasa yang akan digunakan, serta memiliki kemampuan untuk membangun tuturan lebih runut dan runtut(Inhelder, 1978) dan (Bialystok, 1993). Komponen ektralingual terkait dengan faktor di luar bahasa itu sendiri, yakni tempat dan situasi, mitra tutur, tujuan dan kepentingan, sarana dan norma(Hymes, 1974).

Tulisan ini memfokuskan pada kajian tuturan tegur-sapa masyarakat Jawa Pesisir pada sisi kekuatan aspek lingual dalam urutan linier tuturan. Untuk mempertajam analisis ini, beberapa rujukan yang dimanfaatkan, adalah penelitian terkait dengan tuturan Jawa, tingkat tutur Jawa, dan sosial budaya Jawa.

Sudaryanto membagi tingkat tutur bahasa Jawa atas empat tingkatan (Sudaryanto, 1989), yakningoko, ngoko alus, krama, dan krama alus. Pembagian atas empat tingkat tutur ini, menyiratkan adanya konsep lingual halus pada tingkatan ngoko dan krama. Konsep "halus" yang ditawarkan oleh Sudaryanto (1989) lebih bersifat maknawi atau bersangkutan dengan sikap atau memositifkan referen. Pemositifan dapat berarti penghormatan, peninggian, pengluhuran, dan penghargaan.

Mulder (1985) mengungkapkan perihal pandangan masyarakat Jawa: kepribadian - ekspresi kehidupan - hubungan antara pribadi dan masyarakat. Kehidupan bermasyarakat dalam masyarakat Jawa akan dibatasi oleh tatanan atau norma tertentu. Aturan ini (harus) dipatuhi agar dapat tercapai kehidupan yang selaras. Keselarasan yang dimaksudkan disini 
adalah kepatuhan masyarakat untuk mematuhi aturan yang ditetapkan secara konvensional, termasuk di dalamnya penggunaan tuturan (Mulder, 1985).

Suseno (1985) menyatakan bahwa kaidah dasar kehidupan masyarakat Jawa dalamnya terdapat empat prinsip kehidupan, yakni prinsip kerukunan, prinsip hormat, prinsi etika, dan prinsip keselarasan (Suseno, 1984). Keempat prinsip ini menjadi fundamen dan kekuatan untuk hidup bergotong-royong. Ajakan hidup bergotong royong tercermin dari ungkapan-ungkapan Jawa, seperti rame ing gawe sepi ing pamrih, pager mangkok luwih bakoh ketimbang pager tembok, yen olah-olah akeh ana dhudhuhe.

\section{Metode Penelitian}

Lokasi penelitian berada di Kota Semarang sebagai bagian dari Wilayah Pesisir Utara Jawa Tengah. Dasar pertimbangan utamanya adalah telah terjadi pergeseran dan perubahan lingual dalam memahami tingkat tutur bahasa Jawa. Di samping pertimbangan lain, yakni terkait dengan keterbukaan budaya urban yang telah merambah Kota Semarang.

Jenis penelitian ini adalah kualitatif, yakni mengurai dan mendeskripsikan data temuan. Metode pengumpulan data yang dimanfaatkan adalah observasi dan sadap terlibat langsung, yang dilengkapi dengan teknik rekam dan catat (Sudaryanto, 1993). Metode analisis data yang digunakan dalam penelitian ini adalah metode distribusi komponen lingual yang diurai melalui pemilahan kompenen lingual tegur-sapa, untuk mengidentifikasi kekuatan aspek lingual yang membangun tuturan tegur-sapa masyarakat Jawa Pesisir(Sudaryanto, 1993). Di samping itu, mempertimbangkan keberterimaan tuturan melalui sosiokulturalnya(Hymes, 1974).

\section{Hasil dan Pembahasan}

\section{Aspek Lingual dalam Tuturan Jawa Pesisir}

Aspek lingual dalam ilmu bahasa dapat mencakup semua tataran linguistik, yakni: (1) tataran fona, (2) tataran fonem, (3) tataran morfem, (4) tataran kata, (5) tataran frasa, (6) tataran klausa, (7) tataran kalimat, (8) tataran wacana, dan (9) tataran arti dan makna. Setiap tataran tersebut memiliki fitur-fitur yang berbeda baik pada sisi ragam, maupun dialeknya. Fitur tersebut kerapkali yang menjadi ciri pembeda dan keunikan pada tiap tataran. Misal pada tataran kata, akan muncul perbedaan fitur antara ragam krama dengan ragam ngoko, begitu juga ragam ngoko memiliki perbedaan dengan ragam madya. Di samping itu muncul pula perbedaan keunikan pada sisi dialeknya, kerap kali warna dialek 
memberikan warna yang berbeda pada tataran leksikon. Keunikan inilah, yang menjadi salah satu pilihan bahwa tulisan inilebih memfokuskan pada aspek lingualpada tataran leksikon.

Adapun leksikon yang dipilih pada kajian ini adalah leksikon yang muncul dalam tuturan tegur-sapa masyarakat Jawa Kota Semarang. Pada tuturan tegur sapa ini, muncul keterkaitan antara aspek lingual, pilihan leksikon, dan kultur budaya. Pilihan leksikon yang melekat pada tuturan tegur sapa, akan selalui diwarnai dengan kultur budaya dan aspek lingualnya. Kultur budaya mewarnai kekuatan pesan yang disampaikan, sedangkan aspek lingual mewarnai kekuatan semantisnya.

\section{Leksikon Sapaan}

Leksikon sapaan adalah kata atau kelompok kata yang digunakan untuk bertegur-sapa antarpenutur dalam masyarakat tutur. Leksikon ini kerap kali melekat pada tuturan register sevis, prolog, jalinan, akrab, dan impati. Register ini memiliki kesamaan dalam fungsi yakni untuk menjaga keselarasan, keserasian, dan keharmonian hubungan antarmanusia dalam komunitas sosial. Adapun leksikon sapaan ini dapat berwujud (1) sapaan lugu, (2) sapaan kekerabatan, (3) sapaan karya, (4) sapaan pertemanan, (5) sapaanidentitas, (6) sapaan waktu, (7) sapaan prestasi, (8) sapaan penghargaan, (9) sapaan terima kasih dan (9) sapaan religi. Kajian ini lebih memfokuskan pada tuturan sapaan waktu dan sapaan penghargaan. Kedua sapaan ini lebih produktif dalam peristiwa tutur sehari-hari dalam kehidupan masyarakat Jawa Kota Semarang.

Bentuk tegur sapa dalam peristiwa tutur sehari-hari dipengaruhi oleh dua faktor ekstra lingual. Faktor ekstra lingual tersebut berupa relasi antarpartisipan atau antarpeserta tutur (petutur-mitra tutur-mitra yang dituturkan). Relasi tersebut dapat berupa hubungan vertikal maupun hubungan horizontal. Hubungan vertikal memiliki kecenderungan kurang/tidak akrab, sedang hubungan horizontal memiliki kecenderungan sangat akrab. Bentuk hubungan ini berpengaruh terhadap pilihan ragam leksikon tegur sapa. Relasi antarpartisipan dapat dilihat pada bagan 3 . 
Bagan 3: Relasi Tegur Sapa

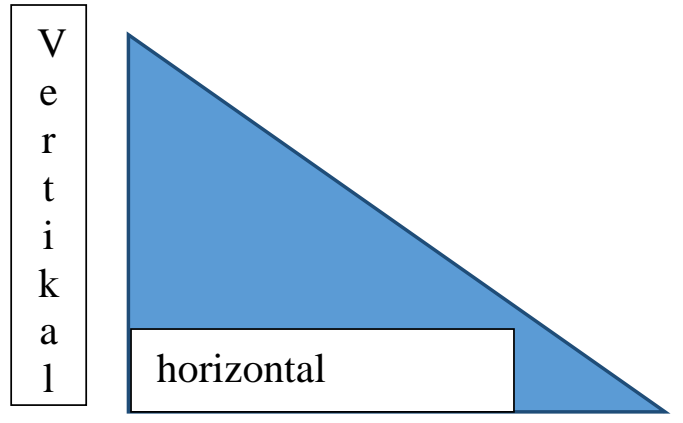

Bentuk tegur-sapa pada relasi vertikal ditandai dengan leksikon ragam krama. Bentuk tegur-sapa horizontal ditandai dengan penggunaan leksikon ragam ngoko dan madya. Pemilahan ragam leksikon ini memiliki korelasi dengan hirarki sosial masyarakat Jawa.

Ragam krama dimanfaatkan untuk menghormati dan menghargai mitra tutur. Pada posisi ini mitra tutur memiliki kedudukan sosial lebih tinggi dibandingkan dengan penutur. Hubungan penutur terhadap mitra tutur kurang akrab atau tidak dikenal. Ragam ngokodan madya dimanfaatkan untuk hubungan akrab dan pertemanan.

\section{Sapaan Waktu}

Sapaan waktu adalah bentuk tegur sapa yang berorientasi pada pembagian waktu. Masyarakat Jawa memiliki pembagian waktu yang sederhana, berbentuk dikotomi, yakni wayah esuk - wayah soredan wayah awan - wayah bengi. Dikotomi ini mengabstraksikan keharmonian atas keseimbangan alam. Pembagian waktu atas (1) wayah esuk 'waktu pagi', (2) wayah awan 'waktu siang', (3) wayah sore 'waktu sore', dan (4) wayah bengi 'waktu malam', tercermin dalam bentuk tegur sapa, sebagai berikut.

(1) sugeng enjang'selamat pagi'

Sapaan sugeng enjang 'selamat pagi' kerap kali digunakan untuk menyapa keharmonian pada tenggang waktu pagi hari. Tenggang waktu yang dimiliki cukup pendek, yakni pada saat matahari terbit sampai bayangan menyamai bendanya.

(2) sugeng siang 'selamat siang' 
Sapaan sugeng siang 'selamat siang' adalah sapaan keharmonian masyarakat Jawa yang memiliki tenggang waktu cukup panjang yakni mulai bayangan timur sebuah benda sampai bayangan baratnya. Tenggang waktu yang cukup panjang ini memiliki korelasi dengan etos kerja dari masyarakat Jawa.

(3) sugeng sonten 'selamat sore'

Sapaan sugeng sonten 'selamat sore' adalah sapaan keharmonian yang digunakan pada sore hari. Tenggang waktu ini sangat pendek, yakni terbatas hanya senja hari. Kerapkali digunakan sebagai waktu pelepas lelah.

(4) sugeng dhalu'selamat malam'

Sapaan sugeng dhalu 'selamat malam' adalah bentuk keakraban untuk merajut keharmonian masyarakat Jawa pada waktu malam hari. Sapaan ini memiliki tenggang waktu yang cukup panjang yakni dari selepas senja sampai fajar tiba.

Keempat sapaan waktu $(1,2,3,4)$ di atas dikategorikan sebagai sapaan waktu ragam krama, karena memiliki relasi vertikal. Hubungan antarapartisipan asimetris, kurang/tidak akrab.

(5) Meruput men 'pagi sekali'

Sapaan waktu meruput men 'pagi sekali' adalah bentuk sapaan yang kerapkali digunakan untuk menyapa mitra tutur yang melakukan kegiatan lebih awal dari kebiasaan waktu yang dilakukan.

(6) Lautan Mas 'istirahat siang hari'

Sapaan waktu lautan Mas 'istirahat siang hari' adalah bentuk tegur sapa yang terkait waktu jeda untuk istirahat, tenggang waktu yang dirujuk pukul 12.00 13.00. Jeda istirahat ini kerapkali digunakan oleh masyarakat Jawa Kota Semarang. Sapaan waktu lautan Mas dikategorikan sebagai sapaan dialektal masyarakat Jawa Kota Semarang.

(7) Bedug-bedug ya 'tengah hari'

Sapaan waktu bedug-bedug ya 'tengah hari' adalah varian bentuk sapaan yang merujuk waktu tengah hari, yakni pukul 12.00 - 13.00. Sapaan ini lebih sering digunakan sebagai tanda untuk segera beristirahat, yang selanjutnya digunakan untuk menjalankan ibadah sholat duhur. Leksikon bedug beranalogi dengan suara bedug yang ditabuh sebagai penanda waktu sholat duhur.

Ketiga sapaan waktu $(5,6,7)$ dikategorikan sebagai tegur sapa ragam ngoko. Sapaan ini memiliki relasi horizontal pada partisipan. Hubungan antarpartisipan sangat akrab dan 
saling mengenal. Pada umumnya sapaan ragam ngokomemiliki kecenderungan bersifat dialektal.

\section{Sapaan Penghargaan}

Sapaan penghargaan adalah salah satu bentuk tegur sapa yang mengedepankan kedudukan dan harkat mitra tutur dalam kehidupan sosial. Sapaan ini memilki fungsi sebagai bentuk penghargaan terhadap diri mitra tutur, terkait dengan kedudukan, jasa, perilaku, dan pertolongan. Bentuk sapaan penghargaan yang ditemukan, yakni:

(8) Nyuwun dhunganipun'minta doa untuk kesalamatan diri'

Sapaan penghargaan nyuwun dhunganipun 'minta doa untuk keselamatan diri' adalah bentuk sapaan yang meninggikan harkat seseorang mitra tutur karena atas jasa dan pertolongan untuk mendoakan sesuatu yang diinginkannya. Sapaan ini sebagai wujud balas budi penutur atas permintaan terhadap mitra tutur untuk mendoakan sesuatu yang diinginkan atau yang dicita-citakan.

(9) Sugeng rawuh 'selamat datang'

Tegur sapaan sugeng rawuh 'selamat datang' adalah bentuk penghargaan terhadap mitra tutur atas undangan yang disampaikan oleh penutur. Sapaan ini sekaligus sebagai simbolik ucapan terima kasih terhadap mitra tutur atas kepeduliannya.

(10) Ati-ati ya 'hati-hati (di jalan) ya'

Sapaan ati-ati ya 'hati-hati ya' adalah bentuk sapaan yang memiliki muatan pesan untuk bertindak lebih hati-hati. Bentuk penghargaan berupa pesan atau nasehat kepada mitra tutur. Kedudukan mitra tutur sejajar dengan penutur, ragam digunakan adalah ngoko.

Bentuk tegur-sapa waktu dan penghargaan pada relasi vertikal, secara umum ditandai dengan penggunaan ragam krama. Pemanfaatan ragam krama ini sebagai akibat dari strata sosial masyarakat Jawa. Fitur lain yang melekat pada relasi vertikal ini adalah kelengkapan strukturnya. Sebaliknya, ragam ngoko dan madyalebih dimanfaatkan pada hubungan lebih akrab dan pertemanan.

\section{Kekuatan Aspek Lingual pada Tuturan Tegur-Sapa Masyarakat Jawa Pesisir}

Kekuatan aspek lingual yang melekat pada tuturan tegur-sapa masyarakat Jawa pesisir dapat dikategorikan atas tiga bagian, yakni aspek yang melekat pada leksikon itu sendiri, 
aspek yang melekat pada posisi sosial, dan aspek yang melekat pada budaya (Suryadi, 2014). Ketiga aspek tersebut tercermin pada bagan-4.

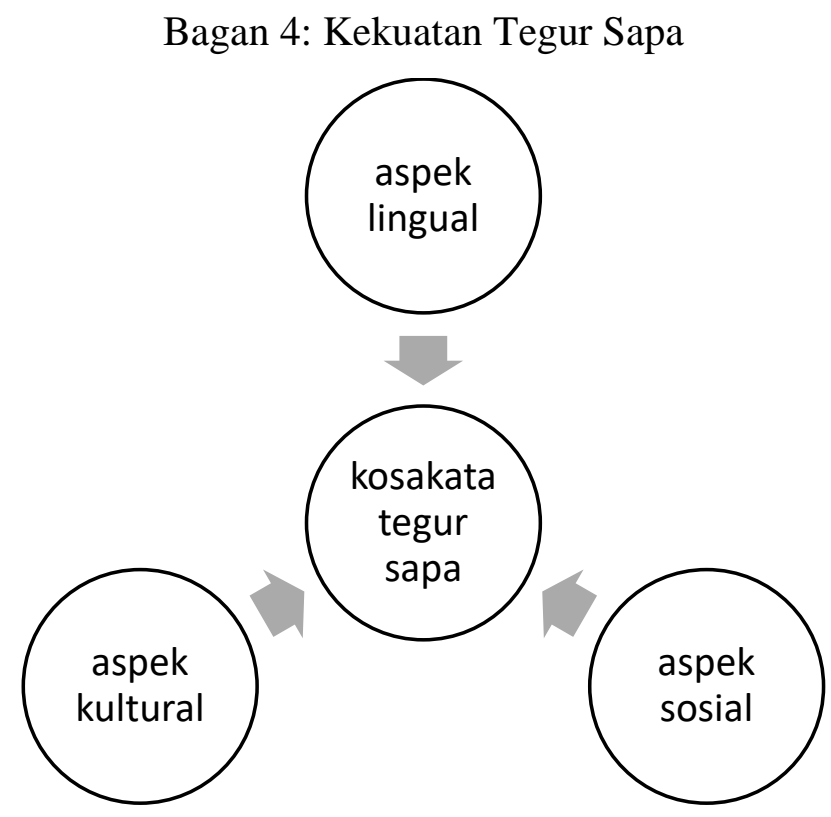

Kekuatan leksikon pada tegur sapa terletak pada tiga aspek, yakni aspek lingual, aspek social, dan aspek kultural. Aspek lingual yang memperkuat daya tegur sapa adalah kecap ujaran,

Aspek lingual yang kerap kali memperkuat daya kekuatan bentuk tegur sapa dalam masyarakat Jawa di Kota Semarang adalah (1) kecap ujaran, (2) kelengkapan bentuk, dan (3) ragam.

Kecap ujaran dalam tuturan tegur sapa cenderung bersifat dialektis dan berada dalam kategori fatis. Kecap ujaran kerapkali muncul pada semua posisi: awal tuturan, tengah tuturan dan akhir tuturan. Fungsi kecap ujaran sebagai penyelaras bunyi dan kekuatan emosional.

Kelengkapan bentuk terkait dengan kelengkapan komponen dalam tuturan. Pada tuturan tegur sapa relasi vertikal memiliki kecenderungan lebih lengkap strukturnya. Kelengkapan ini akibat faktor eksternal yakni menghormati dan menghargai mitra tuturnya.

Apek lingual yang terkait dengan ragam dalam tuturan tegur sapa meliputi ragam tinggi (krama), ragam tengah (madya), dan ragam rendah (ngoko). Manakala aspek lingualnya berada pada ragam krama maka memiliki relasi vertikal dan memiliki 
kelengkapan bentuk. Sebaliknya bilamana berada pada ragam ngoko dan madya berkecenderungan tegur-sapaan tersebut lebih akrab dan santai.

\section{Simpulan}

Hasil analisis tulisan ini menemukan kebaruan dalam tuturan tegur-sapa penutur Jawa di Kota Semarang. Temuan ini adalah tipe-tipe tuturan tegur sapa dan aspek lingual yang mempengaruhi kekuatan tuturan tegur sapa.

Fungsi utama tuturan tegur-sapa yang digunakan oleh penutur Jawa Kota Semarang adalah menjaga keselarasan dan keharmonian dalam kehidupan sosial sehari-hari. Tipe tegur-sapa yang dimiliki adalah tipe vertikal dan horizontal, yang masing-masing meliputi sapaan waktu dan sapaan penghargaan.

Aspek lingual yang mempengaruhi kekuatan tegur-sapa meliputi kecap ujaran, ragam, dan bentuk. Kecap ujaran lebih bersifat lokal-dialek dan berada pada kategori fatis. Ragam dikaitkan dengan hirarki lingual yakni ngoko-madya-krama. Bentuk bertalian dengan kelengkapan dalam strukturnya.

\section{Daftar Pustaka}

Bialystok, E. (1993). Symbolic Representation and attentional Control in Pragmatic Competence. Interlanguage Pragmatica, (pp3-57, 3-57. Retrieved from https://scholar.google.com/scholar?cluster $=136891956440456744 \&$ hl=en\&as_sdt=20 $05 \&$ sciodt $=0,5$

Hymes, D. (1974). Foundations in Sociolinguistics An Ethnographic Approach. Philadelphia: University of Pensylvania Press.

Inhelder, B. (1978). Language and thought: Some remarks on Chomsky and Piaget. Journal of Psycholinguistic Research, 7(4), 263-268. https://doi.org/10.1007/BF01068109

Mulder, N. (1985). Pribadi dan Masyarakat di Jawa (2nd ed.). Jakarta: Pustaka Sinar Harapan.

Sudaryanto. (1989). Pemanfaatan Potensi Bahasa: Kumpulan Karangan sekitar dan tentang Satuan Lingual Bahasa Jawa yang Berdaya Sentuh inderawi (Seri ILDEP). yogyakarta: Kanisius Publishing.

Sudaryanto. (1993). Metode dan aneka teknik analisis bahasa: Pengantar penelitian wahana kebudayaan secara linguistis (Seri ILDEP). yogyakarta: Duta Wacana University Press.

Suryadi, M. (2014). Sebagai Salah Satu Bentuk Kesantunan. Parole, 5(1), 10-13.

Suseno, F. M. (1984). Etika Jawa: Sebuah Analisa Falsafi tentang Kebijaksanaan Hidup Jawa (1st ed.). Jakarta: Gramedia Pustaka Utama. 